\title{
Effects of Storage of Red Cells
}

\author{
Leo M.G. van de Watering ${ }^{\mathrm{a}}$ Anneke Brand ${ }^{\mathrm{a}, \mathrm{b}}$ \\ a Sanquin Division Southwest, \\ ${ }^{b}$ Department of Immunohaematology and Blood Transfusion, Leiden University Medical Center, Leiden, Netherlands
}

\section{Key Words}

Red cell storage $\cdot$ Red cell storage lesion - Transfusion reactions · Adverse transfusion effects · Old blood

\section{Summary}

During storage, red blood cells intended for transfusion undergo progressive changes affecting survival and function. Some of these in vitro changes are partly restored in vivo after transfusion, and their clinical effects are largely unknown. We evaluated publications of clinical studies comparing storage times in connection with red blood cell transfusion using physiological or clinical outcomes. A few prospective randomised studies in humans investigated physiological outcomes or oxygen kinetics. Sixteen observational studies comparing clinical outcome yielded contradictory results regarding the effect of red cell storage on mortality, length of intensive care and hospital stay, infections, organ failure, and composite adverse effects. The use of different red blood cell products further obscures the issue. Available studies provide no evidence that longer stored red cells are more harmful than younger red cells. However, such an effect may occur under extreme clinical conditions of severe anaemia or septicaemia, but this can only be answered by randomised studies controlling for confounding factors.

\section{Schlüsselwörter}

Erythrozytenlagerung · Erythrozytenlagerungsschaden · Transfusionsreaktionen · Schädliche Transfusionseffekte $\cdot$ Altes Blut

\section{Zusammenfassung}

\section{Auswirkungen der Erythrozytenlagerung}

Für die Transfusion vorgesehene Erythrozyten durchlaufen während ihrer Lagerung ständige Veränderungen, die das Überleben und die Funktion der Zellen beeinflussen. Einige dieser In-vitro-Veränderungen werden nach der Transfusion in vivo teilweise rückgängig gemacht, und ihre klinischen Auswirkungen sind größtenteils unbekannt. In der vorliegenden Arbeit werden Publikationen klinischer Studien, die Erythrozytenlagerungszeiten anhand des physiologischen bzw. klinischen Outcome vergleichen, bewertet. Einige am Menschen durchgeführte prospektive, randomisierte Studien haben das physiologische Outcome oder die Sauerstoffkinetik untersucht. Sechzehn Beobachtungsstudien, in denen das klinische Outcome verglichen wurde, erbrachten widersprüchliche Ergebnisse bezüglich des Einflusses der Erythrozytenlagerung auf die Mortalität, die Länge der intensivmedizinischen Behandlung und des Krankenhausaufenthalts, Infektionen, Organversagen sowie verschiedene Nebenwirkungen. Die Verwendung unterschiedlicher Erythrozytenpräparate ist dabei ein zusätzlicher Störfaktor. Vorliegende Studien liefern keine Hinweise darauf, dass länger gelagerte Erythrozyten gesundheitsschädlicher als jüngere Zellen sind. Dies schließt nicht aus, dass unter extremen klinischen Bedingungen wie schwerer Anämie oder Sepsis ein nachteiliger Effekt auftreten kann. Diese Frage kann jedoch nur durch randomisierte Studien, in denen Störgrößen überprüft werden, beantwortet werden.

\begin{tabular}{ll}
\hline KARGER & @ 2008 S. Karger GmbH, Freiburg \\
Fax +497614520714 & Accessible online at: \\
Information@Karger.de & www.karger.com/tmh \\
www.karger.com &
\end{tabular}




\section{Introduction}

The primary function of red blood cells (RBC) is uptake, transport, and delivery of oxygen. In addition, RBC contribute to the colloid osmotic pressure, to platelet-endothelium interactions, and transport of several molecules such as drugs or immune complexes. The aim of RBC transfusions is to treat or prevent tissue hypoxia. Virtually all oxygen is transported by the haemoglobin $(\mathrm{Hb})$. The oxygen supply is further determined by cardiac output and by oxygen uptake capacity in the lung. Under resting circumstances, the oxygen supply exceeds the demand. Overall, only $25-35 \%$ of the available oxygen is extracted by the tissues, although some organs such as the heart, kidney, and brain have a higher basic oxygen extraction ratio of $55-70 \%$ and have less capacity to increase oxygen extraction in response to anaemia [1]. Oxygen supply is not synonymous with oxy Figgen delivery as this requires passage of erythrocytes through the microcirculation and unloading of oxygen, determined by the oxygen dissociation curve, which depends among other factors on acidosis and the red cell enzyme 2,3-diphosphoglycerate (2,3-DPG) (table 1).

During ex-vivo storage, red cells undergo changes affecting function and viability, often collectively referred to as 'storage lesions'. These raised concern for appropriate oxygen delivery, increased adhesion of erythrocytes to endothelium, and impaired deformability necessary for passage through small capillaries; however the clinical relevance is unknown [2-5]. We discuss available clinical studies investigating effects of red cell storage.

\section{Red Cell Products}

For the production of red cells intended for transfusion, in the Western world 450 or $500 \mathrm{ml}$ of whole blood is collected in 63 or $70 \mathrm{ml}$ of CPD-A (citrate-phosphate-dextrose with adenine), respectively. The process of preparing $\mathrm{RBC}$ products varies considerably. Variations concern holding time and temperature before centrifugation by a hard or a soft spin, buffy coat removal, filtration of whole blood or of buffy coat-depleted $\mathrm{RBC}$ to remove leucocytes, or no leucocyte depletion at all. The resulting RBC products have various volumes of residual plasma, platelets, and leucocytes. Red cells can be stored in PVC bags at $2-6{ }^{\circ} \mathrm{C}$ for a period of 5 weeks or longer depending on the red cell preservation solution used. PVC storage bags contain the plasticiser di-ethylhexyl phthalate (DEHP) which accumulates in the red cell membrane and slows down the process of haemolysis and microvesicle formation, and improves red cell survival [6, 7]. Regulations require that $24 \mathrm{~h}$ after transfusion more than $75 \%$ of the cells are recovered in the circulation $[8,9]$. At expiration, the plasma $\mathrm{Hb}$ may not exceed $0.8 \%$ (Europe) or $1 \%$ (USA) of the RBC mass.

It is prudent to realise that available databases which are used in retrospect for clinical studies on the role of aged red cells
Table 1. Factors determining tissue oxygenation relevant for erythrocyte transfusions

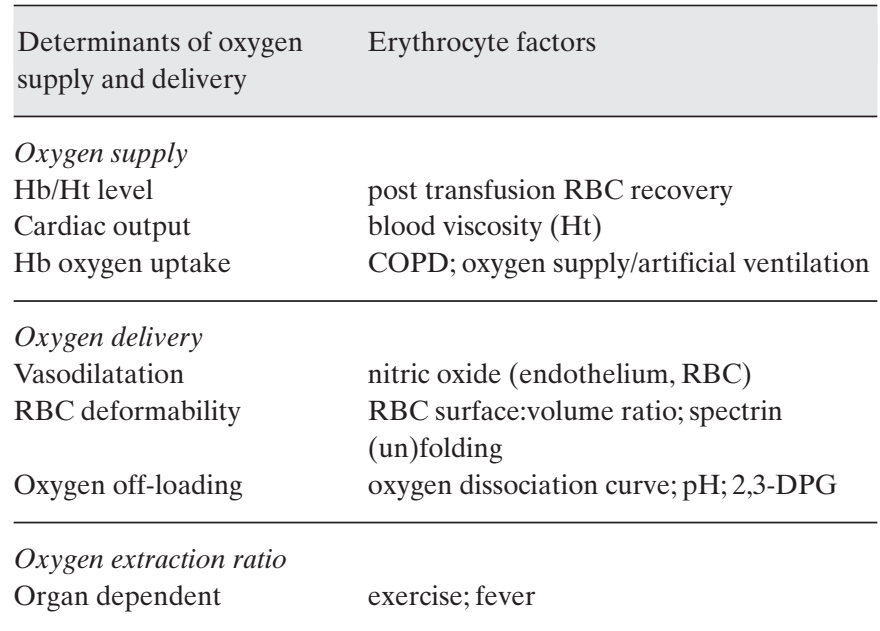

$\mathrm{COPD}=$ Chronic obstructive lung disease $; \mathrm{Ht}=$ haematocrit.

used different RBC products. These studies include packed $\mathrm{RBC}$ containing all leucocytes and platelets, RBC after removal of platelet-rich plasma leaving the majority of leucocytes in the product, buffy coat-depleted RBC in which $>90 \%$ of the platelets and $60-70 \%$ of the leucocytes are removed, and pre-storage filtered whole blood or filtered buffy coat-depleted RBC, virtually depleted from all leucocytes and platelets. Moreover, a variable volume of residual plasma and different preservation solutions (SAG-M, Adsol 1,2,3,5) have been present in these red cell products.

\section{Red Cell Storage Lesions}

Storage lesions, of which the most notable changes are discussed, not only affect red cell properties but also the red cell product suspended in various solutes and containing other residual cells.

\section{Vasodilatory Capacity}

Blood flow in the microcirculation is regulated by nitric oxide (NO) produced by endothelial cells and induced by erythrocytes. When the environmental oxygen tension is low, this is sensed by $\mathrm{Hb}$, and within seconds an adjusted amount of $\mathrm{NO}$ is produced causing a dosed vasodilatation for erythrocyte passage through the vessels, bringing blood flow in line with metabolic demand [10]. Reynolds et al. [11] and BennettGuerrero et al. [12] showed an important role for S-nitrosothiol-Hb (SNO-Hb) for the release of NO. Because SNO-Hb is almost immediately decayed after blood withdrawal and is not restored in vivo, they argue that stored $\mathrm{RBC}$ rather act as a sink for NO, enhancing vasoconstriction. In contrast, Isbell et al. [13] showed SNO-Hb is not essential for erythrocyte-dependent vasodilation, and suggest an adenosine triphosphate (ATP)-dependent mechanism. 
Depletion of 2,3-Diphosphoglycerate (2,3-DPG)

This enzyme binds to de-oxy $\mathrm{Hb}$ forming a complex with low $\mathrm{O}_{2}$ affinity. In the case of anaemia, red cell 2,3-DPG increases after $16-36 \mathrm{~h}$, albeit that this increase is reduced in critically ill septic patients [14]. In RBC stored for 2 weeks, 2,3-DPG is virtually depleted, resulting in a shift of the $\mathrm{O}_{2}$ dissociation curve to the left, impairing oxygen delivery [12]. The reported speed of in vivo restoration of 2,3-DPG after transfusion varies. One hour after transfusion, $25-30 \%$ of 2,3-DPG was measured [15], after $24 \mathrm{~h}$ recovery it is $50 \%$, but full restoration may take up to 3 days [16]. This led to concerns regarding impaired oxygen delivery after transfusion of large amounts of stored RBC. However, studies in baboons [17] and rats [18] found no support for the role for 2,3-DPG as a key factor for off-loading oxygen.

\section{Sodium Potassium Pump}

At $2-6{ }^{\circ} \mathrm{C}$, the $\mathrm{Na}^{+} / \mathrm{K}^{+}$pump is paralysed, and $\mathrm{K}^{+}$leaves the cell while sodium enters it [19]. After 3 days of storage, potassium leaks progressively from the erythrocyte, and the extracellular concentration can increase to $50 \mathrm{mEq} / \mathrm{l}$. After transfusion, the red cell sodium content normalises within $24 \mathrm{~h}$, while complete $\mathrm{K}^{+}$recovery should take at least 4 days [20]. Danger of arrhythmia due to high potassium levels is mainly present with large volume transfusions in newborns and small infants in whom lethal cardiac arrest has been reported [21]. Washing or simply removal of the supernatant are alternatives to reduce potassium toxicity for high-risk recipients [22, 23].

\section{Gamma Irradiation}

Gamma irradiation to prevent transfusion-associated graft versus host disease liberates reactive oxygen species, damages red cell band 3 proteins, increases $\mathrm{K}^{+}$leakage, enhances haemolysis, and impairs at all shear rates the erythrocyte deformability [24, 25]. Gamma irradiation does not enhance RBC aggregation and the adherence of red cells to endothelial cells [26, 27]. Because of lower levels of oxygen radical scavengers, older cells are more susceptible to gamma irradiationinduced damage [28].

\section{Morphology, Deformability, and Viability}

The lipid molecules of the red cell membrane are anchored to different skeletal proteins whose folding and unfolding is essential for cell deformability. The large surface-to-volume ratio of the disc-shaped RBC enables adaptation of shape, minimising the resistance of the $8 \mu \mathrm{m}$-sized red cells during changing flow conditions and passage through smaller capillaries of 3-8 $\mu \mathrm{m}$. During their in vivo lifespan, red cells lose area, volume, and $\mathrm{Hb}$ through vesiculation of 50-200 nm particles [29]. After leaving the bone marrow, 10-14\% of membrane area is lost during reticulocyte maturation, followed by $16-17 \%$ during the remaining lifespan [30, 31]. Extrusion of oxidative waste material of denatured $\mathrm{Hb}$, along with surface area loss, seems a finite process to protect the RBC from pre- mature removal [31, 32]. Exhaustion of this potential may herald the end of red cell lifespan as accumulated denatured $\mathrm{Hb}$ in the red cell membrane may be a sign for binding to natural auto-antibodies which in concert with complement promote partial phagocytosis causing further surface area loss [33-35]. Phosphaditylserine (PS/Annexin V), the death signal, is expressed on $30-70 \%$ of the microvesicles, and $50 \%$ are coated with immunoglobulins resulting in prompt removal by the liver Kupffer cells [30, 36].

During in vitro storage, besides micro-vesiculation in particular of the younger cells [37], red cells also undergo a shape change to echinocytes because of ATP depletion [38]. Initially, this is a reversible process, but towards the end of the in vitro shelf life, irreversible spheroechinocytes are formed, probably due to depletion of the total available adenine nucleotide pool consisting of ATP, adenosine diphosphate (ADP), and adenosine monophosphate (AMP) [39, 40]. On stored red cells, the expression of CD47, a 50-kDa surface transmembrane glycoprotein widely expressed on all cells, reduces by $10-65 \%$ depending on the type of product and assay used [41, 42]. CD47 is presumed to serve as a marker for self, and when expression falls below $50 \%$, the erythrocytes become susceptible for phagocytosis $[41,43]$. Of red cells transfused at the end of the storage time, $20-30 \%$ are non-viable and are removed from the circulation within a few hours. Cells that survive after $24 \mathrm{~h}$, show a normal lifespan, irrespective of storage duration [44].

The Role of Residual Leucocytes and Platelets during Storage Residual leucocytes and platelets influence not only the RBC storage lesion but also, by release of factors, the red cell product. Potassium leakage and haemolysis is less in leucocyte-depleted RBC products [45, 46]. Filtered leucocyte-depleted stored RBC show virtually no increase in PS expression [12], whereas PS becomes expressed in leucocyte-containing RBC products stored as little as 2 weeks. PS-expressing red cells exert pro-coagulant effects and increased adherence potential to endothelium [47, 48], inducing endothelial activation facilitating transendothelial migration of monocytes [49].

In the supernatant of stored non-leucocyte- and platelet-reduced RBC, histamine, complement, lipids, and cytokines can be detected [50]. Cytokines, Il-1 $\beta$, IL-6, IL-8, TNF- $\alpha$, are produced by residual leucocytes, and remain below detection levels in leucocyte-reduced RBC [12,51-54]. On the other hand, filtration has been reported to increase the levels of neutrophil elastase and TGF- $\beta 1$ in RBC [55]. From 2 weeks of storage onwards, the supernatant of leucocyte-containing $\mathrm{RBC}$, but not of leucocyte-depleted RBC, can induce expression of CD11b (C3bi) and CD16 (FCR III) on neutrophils in vitro, with both markers being associated with priming of neutrophils $[49,54]$.

Residual platelets and red cells themselves release factors during RBC storage, such as the pro-inflammatory CD40Ligand and bio-active lipid peroxidases, respectively. Both can prime polymorph-nuclear cells (PMN), and have been proposed as 
Table 2. Clinical studies on storage time and mortality

\begin{tabular}{|c|c|c|c|c|c|c|}
\hline Reference & Design & Population & $\begin{array}{l}\text { Patients, } \\
\mathrm{n}\end{array}$ & Storage time variables & $\begin{array}{l}\text { Adjusting for } \\
\text { confounders }^{\text {a }}\end{array}$ & Results \\
\hline Purdy et al., 1997 [64] & retrospective cohort & sepsis & 31 & mean & no & $\begin{array}{l}17 \text { vs. } 25 \text { days, } \\
\text { p }<0.0001\end{array}$ \\
\hline Edna et al., 1998 [65] & retrospective cohort & colorectal & 336 & mean & yes & NS \\
\hline Mynster and Nielsen, 2001 [66] & prospective cohort & colorectal & 452 & $<21$ vs. $>21$ days & no & NS \\
\hline Gajic et al., 2004 [67] & retrospective cohort & ICU & 181 & $\begin{array}{l}<15 \text { vs. } 15-20 \text { vs. } \\
>20 \text { days }\end{array}$ & no & NS \\
\hline Murrell et al., 2005 [68] & retrospective cohort & trauma & 275 & $\begin{array}{l}\text { dose }(=\text { mean number } \\
\text { of } \mathrm{RBC})^{\mathrm{a}}\end{array}$ & yes & NS \\
\hline Hebert et al., 2005 [69] & $\mathrm{RCT}$ & cardiac + ICU & 57 & $\begin{array}{l}<8 \text { days (median } 4 \text { days) } \\
\text { vs. standard (median } 19 \text { days) }\end{array}$ & no & NS \\
\hline Basran et al., $2006[70,84]$ & retrospective cohort & cardiac & 321 & mean + oldest RBC & yes & $\begin{array}{l}\text { both show } \\
\text { increased } \\
\text { in-hospital } \\
\text { mortality }\end{array}$ \\
\hline Van de Watering et al., 2006 [71] & retrospective cohort & cardiac & 2,732 & $\begin{array}{l}\text { mean }+ \text { oldest }+ \text { youngest } \\
+<18 \text { vs. }>18 \text { days }^{\text {b }}\end{array}$ & yes & NS \\
\hline Leal-Noval et al., 2008 [72] & prospective cohort & trauma & 66 & $\begin{array}{l}<10 \text { vs. } 10-14 \text { vs. } 15-19 \text { vs. } \\
>19 \text { day }\end{array}$ & no & NS \\
\hline Koch et al., 2008 [73] & retrospective cohort & cardiac & 6,002 & $<14$ vs. $>14$ days & no & $\begin{array}{l}1.7 \text { vs. } 2.8 \% \\
p=0.004\end{array}$ \\
\hline Yap et al., 2008 [74] & retrospective cohort & cardiac & 670 & $\begin{array}{l}\text { mean }+ \text { oldest } \\
+(y / n)>30 \text { days }\end{array}$ & yes & NS \\
\hline Weinberg et al., 2008 [75] & retrospective cohort & trauma & 1,813 & $<14$ vs. $\geq 14$ days & yes & $\mathrm{NS}^{\mathrm{c}}$ \\
\hline
\end{tabular}

NS = No significant independent association found between storage time and mortality; RCT = randomised clinical trial; $\mathrm{y} / \mathrm{n}=\mathrm{yes} / \mathrm{no}$.

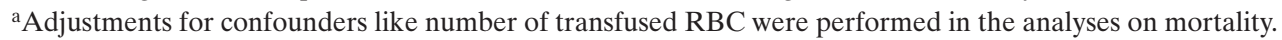

${ }^{b} 1,895$ patients in analyses $<18$ days (945) vs. $>18$ days (950).

'Only in subgroup analysis significant associations were found.

(co-)factors causing transfusion-related acute lung injury (TRALI) [56-58]. RBC supernatants harvested after 15 days storage from filtered leucocyte-depleted as well as from nonfiltered $\mathrm{RBC}$ increase the oxidative potential of PMN in response to N-formyl-methionyl-leucyl-phenylalanine (fMLP), a chemotactic peptide stimulating the oxidative burst [54]. The role of storage of red cells causing febrile non-haemolytic transfusion reactions (FNHTR) and TRALI has indeed often been questioned, but randomised studies have not yet been performed [59, 60]. Heddle et al. [59], by application of multivariate regression analysis in a prospective study, identified the number of contaminating leucocytes and the age of the $\mathrm{RBC}$ component as the most significant factors associated with FNHTR [59].

Although RBC expressing PS show enhanced endothelial adherence and pro-coagulant activity, and RBC supernatants can induce priming of PMN - factors that may play a role in causing TRALI, the exact contribution of aged RBC products to TRALI is not yet known.

\section{Physiological Studies in Humans}

\section{Oxygen Kinetics}

Hebert and Chin-Yee [4] reviewed 14 observational studies in critically ill patients estimating the effect of RBC transfusions on oxygen delivery, oxygen consumption, and lactate levels. A striking number of studies showed no improvement in these parameters. Again, the use of different blood products may explain some of the discordant outcomes. Marik et al. [61] found in a prospective study measuring gastric mucosal oxygenation that 3 units of (leucocyte-containing) RBC stored longer than 15 days, impaired gastric mucosal $\mathrm{pH}$ indicating lower oxygen release. This study was repeated in a doubleblinded randomised trial, assigning patients to 2 units of RBC stored $<5$ days (mean 2 ) or $>20$ days (mean 28), which had been leucocyte-reduced before storage and stored in SAG-M solution. This study found no support of any difference in oxygenation index between the storage groups, but also no improvement as compared to baseline values [62]. In an elegant 


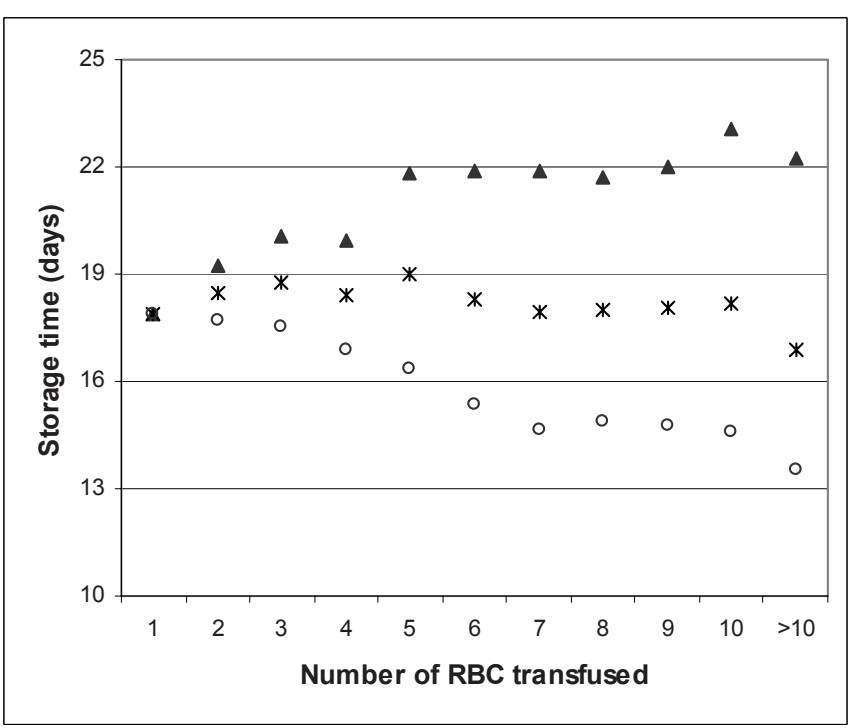

Fig. 1. Correlation of total number of transfused $R B C$ with storage time variables.

Correlation of the total number of RBC transfused with the 3 storage time variables: $(\mathbf{\Lambda})$ mean storage time of the oldest RBC/patient; $(\boldsymbol{*})$ mean storage time of all RBC/patient; ( 0 ) mean storage time of the youngest $\mathrm{RBC} /$ patient.

Reproduced with permission from van de Watering L, Lorinser J, Versteegh M, Westendorp R, Brand A: Effects of storage time of red blood cell transfusions on the prognosis of coronary artery bypass graft patients. Transfusion 2006;46(10):1712-8. @Transfusion, 2006 .

study in healthy volunteers, Weiskopf et al. [63] showed that absence of 2,3-DPG in non-leucocyte-reduced RBC stored up to 2-3 weeks improved cognitive functions in acute normovolaemic anaemia with $\mathrm{Hb}$ of $5-6 \mathrm{~g} / \mathrm{dl}$.

\section{Studies with Clinical (Surrogate) Endpoints}

Dozens of studies have been performed investigating the association between clinical outcome and the transfusion of stored RBC. However, only a minority of these have actually investigated the role of the storage time of the RBC. The clinical setting was most often in trauma, intensive care unit (ICU), cardiac, or (colo)rectal surgery patients. Clinical outcome was analysed using endpoints like mortality [64-75], ICU/hospital stay [67, 68, 70-72, 74, 76-79], infectious complications [67, 73, $74,79-82]$, intubation days [77-79], (multiple) organ failure $[69,70,74,83]$, and composites of specific adverse outcomes $[69,73,79,80]$. Nearly all studies are observational, and therefore mostly associations are reported.

\section{Storage Time and Mortality}

The most investigated association is that between the storage time of RBC and mortality (table 2). In 1997, Purdy et al. [64] reported, in a population of 31 transfused septic patients, a significant longer mean storage time of transfused
RBC in patients that died (25 days) versus survivors (17 days), $\mathrm{p}<0.0001$. One year later, Edna et al. [65] could not see any independent association between mean storage time and survival. And Mynster and Nielsen [66], in 2001, reported even a small beneficial effect of prolonged ( $>21$ days) storage in transfused colorectal surgery patients, mostly due to significantly less cancer recurrence. Gajic et al. [67] stratified his patient population according to the mean storage time of the transfused RBC into ' $<15$ days', '15-20 days', '> 20 days'. These strata showed similar mortality rates ( 0.30 vs. 0.30 vs. $0.26 ; p=0.869)$. Two studies published in 2005 on this subject, both failed to find an association with mortality. Murrell et al. [68] did not find an association between the dose of aged blood and mortality in major trauma patients. Neither did Hebert et al. [69] reporting on a randomised pilot study in 57 transfused cardiac/ICU patients receiving either standard RBC (mean storage time: 19 days) or $\mathrm{RBC}$ stored $<8$ days (mean 4 days). Then, in 2006, Basran et al. [70] reported mortality to be associated with both the mean storage time and the maximum storage time of the transfused RBC, in transfused cardiac surgery patients. However, the reported results showed some inconsistencies which could not be corrected, as the used dataset had been lost [84]. Also in 2006, van de Watering et al. [71] reported analyses on 2,732 coronary artery bypass graft (CABG) patients that showed an association in univariate analyses between mortality and the storage time of both the oldest and the youngest RBC transfused. However, both these storage time variables were strongly correlated with the total number of $\mathrm{RBC}$ transfused, as shown in figure 1, and the multivariate analyses adjusting for this imbalance showed absolutely no independent correlation of storage times with mortality (both $\mathrm{p}>0.95$ ). The mean storage time and the subgroups with all $\mathrm{RBC}$ stored $<18$ days vs. all $\mathrm{RBC}$ stored $>18$ days were in none of the analyses associated with mortality. In the study of Leal-Noval et al. [72] in patients receiving 1 or 2 $\mathrm{RBC}$, the storage time was stratified into ' $<10$ days', '10-14 days', '15-19 days', and '> 19 days'. The analyses showed no association between these strata and mortality. In 2008, Koch et al. [73] reported on 6,002 cardiac surgery patients, receiving all their $\mathrm{RBC}$ either $\leq 14$ days or all $>14$ days old. A significant association of mortality with storage time was reported ( $\mathrm{p}=0.004)$, but shortcomings in this analysis (e.g. no adjusting for confounders like the number of RBC transfused) lead to several letters in response [85]. Yap et al. [74] analysed mean storage time, the oldest RBC and if any RBC stored $>30$ days had been transfused, in 670 cardiac surgery patients. None of these variables were independently associated with mortality. Weinberg et al. [75] analysed storage, stratifying the number of filtered $\mathrm{RBC}<14$ days and $\geq 14$ days into $0,1-2$, or $\geq 3 \mathrm{RBC}$ in 1,813 transfused trauma patients. Both 'young 'and 'old' RBC increased the odds of death, but this was stronger with old blood. The unadjusted association of the storage time of transfused RBC with mor- 
Table 3. Clinical studies on storage time and (ICU and/or hospital) length of stay

\begin{tabular}{|c|c|c|c|c|c|c|}
\hline Reference & Design & Population & $\begin{array}{l}\text { Patients, } \\
\mathrm{n}\end{array}$ & Storage time variables & $\begin{array}{l}\text { Adjusting for } \\
\text { confounders }^{\text {a }}\end{array}$ & Results \\
\hline Martin et al., 1994 [76] & retrospective cohort & $\mathrm{ICU}$ & 698 & $<14$ vs. $>14$ days & yes & $\begin{array}{l}\text { ICU length of } \\
\text { stay } p=0.003\end{array}$ \\
\hline Vamvakas and Carven, 2000 [77] & retrospective cohort & cardiac & 269 & $\begin{array}{l}\text { mean }+ \text { oldest }+ \text { mean of } \\
2 \text { oldest }\end{array}$ & yes & NS \\
\hline Keller et al., $2002[78,86]$ & retrospective cohort & trauma & 86 & number of $\mathrm{RBC}>14$ days & yes & NS \\
\hline Leal-Noval et al., 2003 [79] & prospective cohort & cardiac & 585 & mean + oldest RBC & yes & NS \\
\hline Gajic et al. 2004 [67] & retrospective cohort & ICU & 181 & $<15$ vs. $15-20$ vs. $>20$ days & no & NS \\
\hline Murrell et al., 2005 [68] & retrospective cohort & trauma & 275 & $\begin{array}{l}\text { dose }(=\text { mean } \times \text { number } \\
\text { of } \mathrm{RBC})\end{array}$ & yes & $\begin{array}{l}\text { dose aged } \\
\text { blood } \Rightarrow \text { in- } \\
\text { creased ICU } \\
\text { length of stay }\end{array}$ \\
\hline Basran et al. $2006[70,84]$ & retrospective cohort & cardiac & 321 & mean + oldest RBC & yes & $\begin{array}{l}\text { oldest RBC } \\
\Rightarrow \text { increased } \\
\text { both ICU }+ \\
\text { hospital length } \\
\text { of stayc }^{\text {c }}\end{array}$ \\
\hline Van de Watering et al. 2006 [71] & retrospective cohort & cardiac & 2732 & $\begin{array}{l}\text { mean }+ \text { oldest }+ \text { youngest } \\
+<18 \text { vs. }>18 \text { days }^{\mathrm{d}}\end{array}$ & yes & NS \\
\hline Leal-Noval et al., 2008 [72] & prospective cohort & trauma & 66 & $\begin{array}{l}<10 \text { vs. } 10-14 \text { vs. } 15-19 \text { vs. } \\
>19 \text { days }\end{array}$ & no & NS \\
\hline Yap et al., 2008 [74] & retrospective cohort & cardiac & 1,813 & $\begin{array}{l}\text { mean + oldest }+(y / n) \\
>30 \text { days }\end{array}$ & yes & NS \\
\hline
\end{tabular}

NS = No significant independent association found between storage time and ICU length of stay.

${ }^{a}$ Adjustments for confounders like number of transfused RBC were performed in the analyses on ICU length of stay.

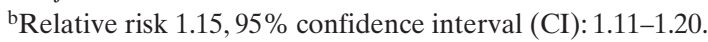

'Inconsistencies in reported hazard ratios, $95 \%$ CIs, and p values could not be corrected due to loss of the dataset [84]

d 1,895 patients in analyses $<18(945)$ vs. $>18$ days $(950)$

tality, as initially reported in a small $(\mathrm{n}=31)$ study, was not reliably confirmed as independent association in any of the 11 succeeding larger studies.

\section{Storage Time and Length of Stay}

An association between storage time of RBC and length of ICU stay (table 3) was reported by Martin et al. [76] in 1994. In 698 ICU patients, the transfusion of RBC stored $>14$ days was independently associated with the length of ICU stay. Vamvakas and Carven [77] investigated in CABG patients the association with both ICU and hospital length of stay, using mean storage time of all $\mathrm{RBC}$, the storage time of the oldest $\mathrm{RBC}$, and the mean of the 2 oldest RBC. After adjustment for confounding factors, none of the storage time variables were associated with either length of ICU stay or hospital stay. Keller et al. [78] investigated both these associations in trauma patients, using the number of RBC stored $>14$ days as variable. In all their models adjusting for confounding, no association was found with length of ICU stay. Length of hospital stay was only independently associated in the multivariate models not including the number of RBC transfused [86]. Leal-Noval et al. [79] reported in 2003 their study in cardiac surgery patients. Neither the mean storage time of all RBC nor the storage time of the oldest RBC was associated with length of ICU stay. Gajic et al. [67] stratifying his population of mechanically ventilated patients on mean RBC storage into ' $<15$ days', '15-20 days', '> 20 days' also found no association of these strata with length of ICU stay. The study by Murrell et al. [68] in trauma patients reported that the dose of aged blood (defined as the average age of received RBC multiplied by the number of RBC received) was significantly correlated with longer ICU stay. From the 2 studies in 2006 on this topic in cardiac surgery patients, Basran et al. [70, 84] reported an association of the length of both ICU and hospital stay with the storage time of the oldest RBC, but not with the mean storage time or even the number of transfusions. The study by van de Watering et al. [71] showed strong associations between the storage time of both the youngest and the oldest RBC in the unadjusted univariate analyses, that completely disappeared in the multivariate analyses adjusting for confounders. Again, no associations were seen with the mean storage time or in the subgroups with all $\mathrm{RBC}<18$ days vs. all $\mathrm{RBC}>18$ days, 
analysing 2,732 and 1,895 (945 vs. 950) patients, respectively. The study by Leal-Noval et al. [72] stratifying brain trauma patients on RBC storage time into ' $<10$ days', '10-14 days', '15-19 days', and '> 19 days' showed no association between these strata and length of ICU or hospital stay. Yap et al. [74] reported that neither the mean storage time nor the oldest $\mathrm{RBC}$ or any $\mathrm{RBC}>30$ days old were independently associated with the postoperative ICU length of stay. Like with the studies on the association with mortality, the initially reported association of the storage time of transfused $\mathrm{RBC}$ with ICU/hospital length of stay was not reliably confirmed as independent association in any of the succeeding studies.

\section{Storage Time and Infectious Complications}

A possible association between storage time of RBC and infectious complications is investigated using several different endpoints. Vamvakas and Carven [80], investigating transfused CABG patients, reported both their composite outcome (wound infection or pneumonia) and pneumonia by itself to be associated with both the mean length of storage of all RBC and the mean length of storage of the 2 oldest RBC. Mynster and Nielsen [82] found in rectal cancer patients $60 \%$ of RBC were stored for $>20$ days in patients with postoperative infections versus only $25 \%$ of $\mathrm{RBC}$ in patients without infections. Offner et al. [81] investigated in trauma patients the association between infection and the number of RBC stored $>14$ days or $>21$ days. To correct for the total number of RBC transfused, the analyses were performed in 3 strata (6-10 RBC; 11-15 RBC; 16-20 RBC). An independent association with infection was seen in 1 of the 3 strata analysed for both the number of $\mathrm{RBC}>14$ days (in 6-10 RBC) and $>21$ days (in 16-20 RBC). Leal-Noval et al. [79] saw in cardiac surgery patients no independent association between the mean or maximum storage time and their composite endpoint infection (pneumonia, sepsis, mediastinitis). However, in subgroup analyses, storage of the oldest RBC longer than 28 days was identified as risk factor for nosocomial pneumonia. The study by Gajic et al. [67] comparing patients with a mean RBC storage $<15,15-20$, or $>20$ days found no association of these strata with the occurrence of sepsis. Yap et al. [74] found no association between postoperative pneumonia and mean storage time, oldest RBC, or storage time $>30$ days. Although both the type of infectious complications investigated and the way storage time was analysed differed between the studies, an association between storage time and infectious complications was repeatedly reported.

\section{Storage Time and Organ Failure}

Other studies reporting on associations between storage time of RBC and clinical endpoints mostly report on some type of organ failure. Zallen et al. [83] reported in their study in trauma patients an association between the mean storage time, the number of RBC stored $>14$ days, and the number of RBC stored $>21$ days with the occurrence of multiple organ failure. Respiratory failure (period of intubation or acute lung injury) was analysed in 5 studies. Vamvakas and Carven [77] found no association with the mean storage time of all RBC, the storage time of the oldest RBC, or the mean of the 2 oldest $\mathrm{RBC}$, Keller et al. [78] found no association with the number of RBC stored > 14 days, Leal-Noval et al. [79] reported no association with the mean storage time or the storage time of the oldest RBC, Gajic et al. [67] found no difference in their analyses stratified on mean storage time, and Hebert et al. [69] found no difference in their randomised controlled trial in patients receiving either standard RBC (mean storage time: 19 days) or RBC stored $<8$ days (mean 4 ). This last study also found no differences in cardiac or renal support. Renal dysfunction was reported to be associated with both the mean and the maximum storage time by Basran et al. [70], although the precise magnitude of this association remains unclear [84]. Koch et al. [73, 85], comparing patients receiving either all their RBC stored $\leq 14$ days or all $>14$ days, reported associations with respiratory failure, renal failure, and multiple organ failure, only in their unadjusted analyses. Yap et al. [74] found, after adjusting for number of transfusions and Euroscore, no association between renal failure and mean storage time, oldest $\mathrm{RBC}$, or storage time $>30$ days.

\section{Conclusions}

There is no clear consensus on possible associations between storage time and morbidity or mortality. The results on infectious complications are most consistent, but with the other endpoints there seem to be additional variables, maybe unreported or even unrecorded, that play a major role. Publication bias may have played some role as more of the older, smaller, studies report independent associations. Furthermore, some studies failed to correct for known confounders, like the number of RBC transfused. Another explanation may be sought with the fact that apart from infectious complications, associations are reported in most of the North American studies and in none of the European studies. Differences in production techniques, storage media, or cellular composition of the blood products used in these studies may be part of the explanation. The registered randomised controlled trials on storage time (ClinicalTrials.gov identifiers: NCT00141674 \& NCT 00458783) may come up with answers for North America, but if their results will also be applicable for Europe will need further, intercontinental research. 


\section{References}

1 Crosby E: Re-evaluating the transfusion trigger: how low is safe? Am J Ther 2002;9:411-6.

2 Ho J, Sibbald WJ, Chin-Yee IH: Effects of storage on efficacy of red cell transfusion: when is it not safe? Crit Care Med 2003;31:S687-S697.

$\checkmark 3$ Tinmouth A, Fergusson D, Yee IC, Hebert PC: Clinical consequences of red cell storage in the critically ill. Transfusion 2006;46:2014-27.

4 Hebert PC, Chin-Yee I: Clinical consequences of prolonged blood storage: should old red blood cells be transfused in critically ill patients? Transfus Altern Transfus Med 2001;2:19-25.

5 Adamson JW: New blood, old blood, or no blood? N Engl J Med 2008;358:1295-6.

6 AuBuchon JP, Estep TN, Davey RJ: The effect of the plasticizer di-2-ethylhexyl phthalate on the survival of stored RBCs. Blood 1988;71:448-52.

7 Deepa Devi KV, Manoj K, V, Arun P, Santhosh A, Padmakumaran Nair KG, Lakshmi LR, Kurup PA: Increased lipid peroxidation of erythrocytes in blood stored in polyvinyl chloride blood storage bags plasticized with di-[2-ethyl hexyl] phthalate and effect of antioxidants. Vox Sang 1998;75: 198-204.

8 Brecher ME (ed): Technical manual. 14 ed. Bethesda: AABB; 2002.

9 Guide to the preparation, use and quality assurance of blood components, $13 \mathrm{ed}$. Strasbourg, Council of Europe, 2007.

10 James PE, Lang D, Tufnell-Barret T, Milsom AB, Frenneaux MP: Vasorelaxation by red blood cells and impairment in diabetes: reduced nitric oxide and oxygen delivery by glycated hemoglobin. Circ Res 2004;94:976-83.

11 Reynolds JD, Ahearn GS, Angelo M, Zhang J, Cobb F, Stamler JS: S-nitrosohemoglobin deficiency: a mechanism for loss of physiological activity in banked blood. Proc Natl Acad Sci USA 2007;104: 17058-62.

$\checkmark 12$ Bennett-Guerrero E, Veldman TH, Doctor A, Telen MJ, Ortel TL, Reid TS, Mulherin MA, Zhu H, Buck RD, Califf RM, et al.: Evolution of adverse changes in stored RBCs. Proc Natl Acad Sci USA 2007; 104:17063-8.

13 Isbell TS, Sun CW, Wu LC, Teng X, Vitturi DA, Branch BG, Kevil CG, Peng N, Wyss JM, Ambalavanan $\mathrm{N}$, et al.: SNO-hemoglobin is not essential for red blood cell-dependent hypoxic vasodilation. Nat Med 2008;14:773-7.

14 Ibrahim ED, McLellan SA, Walsh TS: Red blood cell 2,3-diphosphoglycerate concentration and in vivo P50 during early critical illness. Crit Care Med 2005;33:2247-52.

15 Beutler E, Wood L: The in vivo regeneration of red cell 2,3 diphosphoglyceric acid (DPG) after transfusion of stored blood. J Lab Clin Med 1969;74: $300-4$.

16 Valeri CR, Collins FB: Physiologic effects of transfusing preserved red cells with low 2,3 diphosphoglycerate and high affinity for oxygen. Vox Sang 1971;20:397-403.

17 Valeri CR, Rorth M, Zaroulis CG, Jakubowski MS, Vescera SV: Physiologic effects of transfusing red blood cells with high or low affinity for oxygen to passively hyperventilated, anemic baboons: systemic and cerebral oxygen extraction. Ann Surg 1975;181:106-13.

18 Raat NJ, Verhoeven AJ, Mik EG, Gouwerok CW, Verhaar R, Goedhart PT, de Korte D, Ince C: The effect of storage time of human red cells on intestinal microcirculatory oxygenation in a rat isovolemic exchange model. Crit Care Med 2005;33: 39-45.
19 Kerger H, Waschke KF, Ackern KV, Tsai AG, Intaglietta M: Systemic and microcirculatory effects of autologous whole blood resuscitation in severe hemorrhagic shock. Am J Physiol 1999;276: 2035-46.

20 Hogman CF, Meryman HT: Storage parameters affecting red blood cell survival and function after transfusion. Transfus Med Rev 1999;13:275-96.

21 Klein HG, Spahn DR, Carson JL: Red blood cell transfusion in clinical practice. Lancet 2007;370: 415-26.

22 Weiskopf RB, Schnapp S, Rouine-Rapp K, Bostrom A, Toy P: Extracellular potassium concentrations in red blood cell suspensions after irradiation and washing. Transfusion 2005;45:1295-301.

23 Bansal I, Calhoun BW, Joseph C, Pothiawala M, Baron BW: A comparative study of reducing the extracellular potassium concentration in red blood cells by washing and by reduction of additive solution. Transfusion 2007;47:248-50.

24 Rivet C, Baxter A, Rock G: Potassium levels in irradiated blood. Transfusion 1989:29:185.

25 Hillyer CD, Tiegerman KO, Berkman EM: Evaluation of the red cell storage lesion after irradiation in filtered packed red cell units. Transfusion 1991; 31:497-9.

26 Relevy H, Koshkaryev A, Manny N, Yedgar S, Barshtein G: Blood banking-induced alteration of red blood cell flow properties. Transfusion 2008; 48 : 136-46.

27 Anand AJ, Dzik WH, Imam A, Sadrzadeh SM: Radiation-induced red cell damage: role of reactive oxygen species. Transfusion 1997;37:160-5.

28 Moroff G, Holme S, AuBuchon JP, Heaton WA, Sweeney JD, Friedman LI: Viability and in vitro properties of AS-1 red cells after gamma irradiation. Transfusion 1999;39:128-34

29 Willekens FL, Bosch FH, Roerdinkholder-Stoelwinder B, Groenen-Dopp YA, Werre JM: Quantification of loss of haemoglobin components from the circulating red blood cell in vivo. Eur J Haematol 1997;58:246-50.

30 Werre JM, Willekens FL, Bosch FH, de Haans LD, van d, V, van den Bos AG, Bosman GJ: The red cell revisited-matters of life and death. Cell Mol Biol (Noisy-le-grand) 2004;50:139-45.

31 Gifford SC, Derganc J, Shevkoplyas SS, Yoshida T, Bitensky MW: A detailed study of time-dependent changes in human red blood cells: from reticulocyte maturation to erythrocyte senescence. Br J Haematol 2006;135:395-404.

32 Willekens FL, Werre JM, Groenen-Dopp YA, Roerdinkholder-Stoelwinder B, de PB, Bosman GJ: Erythrocyte vesiculation: a self-protective mechanism? Br J Haematol 2008;141:549-56.

33 Schluter K, Drenckhahn D: Co-clustering of denatured hemoglobin with band 3: its role in binding of autoantibodies against band 3 to abnormal and aged erythrocytes. Proc Natl Acad Sci USA 1986; 83:6137-41.

34 Kay MM, Marchalonis JJ, Schluter SF, Bosman G: Human erythrocyte aging: cellular and molecular biology. Transfus Med Rev 1991;5:173-95.

35 Kitamura H, Nagano A, Kitano E: Hemolysis of normal human erythrocytes by autologous serum complement. Int Arch Allergy Immunol 1993;100: 209-14.

36 Willekens FL, Werre JM, Kruijt JK, Roerdinkholder-Stoelwinder B, Groenen-Dopp YA, van den Bos AG, Bosman GJ, van Berkel TJ: Liver Kupffer cells rapidly remove red blood cell-derived vesicles from the circulation by scavenger receptors. Blood 2005; 105:2141-5.
37 Greenwalt TJ, Dumaswala UJ. Effect of red cell age on vesiculation in vitro. Br J Haematol 1988;68: 465-7.

38 Nakao M, Nakao T, Yamazoe S: Adenosine triphosphate and maintenance of shape of the human red cells. Nature 1960;187:945-6.

39 Hogman CF, de Verdier CH, Ericson A, Eriksson L, Sandhagen B: Studies on the mechanism of human red cell loss of viability during storage at +4 degrees $\mathrm{C}$ in vitro. III. Effects of mixing during storage. Vox Sang 1987;53:84-8.

40 Hess JR, Greenwalt TG: Storage of red blood cells: new approaches. Transfus Med Rev 2002;16:283-95.

41 Stewart A, Urbaniak S, Turner M, Bessos H: The application of a new quantitative assay for the monitoring of integrin-associated protein CD47 on red blood cells during storage and comparison with the expression of CD47 and phosphatidylserine with flow cytometry. Transfusion 2005;45:1496-503.

42 Anniss AM, Sparrow RL: Expression of CD47 (integrin-associated protein) decreases on red blood cells during storage. Transfus Apher Sci 2002;27: 233-8.

43 Oldenborg PA, Zheleznyak A, Fang YF, Lagenaur CF, Gresham HD, Lindberg FP: Role of CD47 as a marker of self on red blood cells. Science 2000;288: 2051-4.

44 Luten M, Roerdinkholder-Stoelwinder B, Schaap N, de Grip W, Bos H, Bosman GJ: Survival of red blood cells after transfusion: a comparison between red cells concentrates of different storage periods. Transfusion 2008;48:1478-85.

45 Greenwalt TJ, Zehner SC, Dumaswala UJ: Studies in red blood cell preservation. 1. Effect of the other formed elements. Vox Sang 1990;58:85-9.

46 Heaton WA, Holme S, Smith K, Brecher ME, Pineda A, AuBuchon JP, Nelson E: Effects of 3-5 $\log 10$ pre-storage leucocyte depletion on red cell storage and metabolism. Br J Haematol 1994;87:363-8.

47 Luk CS, Gray-Statchuk LA, Cepinkas G, Chin-Yee IH: WBC reduction reduces storage-associated $\mathrm{RBC}$ adhesion to human vascular endothelial cells under conditions of continuous flow in vitro. Transfusion 2003;43:151-6.

48 Arslan E, Sierko E, Waters JH, Siemionow M: Microcirculatory hemodynamics after acute blood loss followed by fresh and banked blood transfusion. Am J Surg 2005;190:456-62.

49 Anniss AM, Sparrow RL: Storage duration and white blood cell content of red blood cell (RBC) products increases adhesion of stored RBCs to endothelium under flow conditions. Transfusion 2006; 46:1561-7.

50 Nielsen HJ: Transfusion-associated immunomodulation: experimental facts and clinical reality - new perspectives. Transfus Med Hemother 2006;33: 324-9.

51 Shanwell A, Kristiansson M, Remberger M, Ringden O: Generation of cytokines in red cell concentrates during storage is prevented by prestorage white cell reduction. Transfusion 1997;37:678-84.

52 Stack G, Baril L, Napychank P, Snyder EL: Cytokine generation in stored, white cell-reduced, and bacterially contaminated units of red cells. Transfusion 1995;35:199-203.

53 Muylle L, Peetermans ME: Effect of prestorage leukocyte removal on the cytokine levels in stored platelet concentrates. Vox Sang 1994;66:14-7.

54 Chin-Yee I, Keeney M, Krueger L, Dietz G, Moses G: Supernatant from stored red cells activates neutrophils. Transfus Med 1998;8:49-56. 
-55 Tylman M, Bengtson JP, Hyllner M, Bengtsson A: Release of PMN elastase, TGF-beta1 and neopterin during blood storage; unfiltered versus filtered blood. Transfus Apher Sci 2006:35:97-102.

\$56 Khan SY, Kelher MR, Heal JM, Blumberg N, Boshkov LK, Phipps R, Gettings KF, McLaughlin NJ, Silliman CC: Soluble CD40 ligand accumulates in stored blood components, primes neutrophils through CD40, and is a potential cofactor in the development of transfusion-related acute lung injury. Blood 2006;108:2455-62.

57 Silliman CC, Clay KL, Thurman GW, Johnson CA, Ambruso DR: Partial characterization of lipids that develop during the routine storage of blood and prime the neutrophil NADPH oxidase. J Lab Clin Med 1994;124:684-94.

58 Silliman CC, Voelkel NF, Allard JD, Elzi DJ, Tuder RM, Johnson JL, Ambruso DR: Plasma and lipids from stored packed red blood cells cause acute lung injury in an animal model. J Clin Invest 1998;101: 1458-67.

59 Heddle NM, Klama LN, Griffith L, Roberts R, Shukla G, Kelton JG: A prospective study to identify the risk factors associated with acute reactions to platelet and red cell transfusions. Transfusion 1993; 33:794-7.

60 Silliman CC, Boshkov LK, Mehdizadehkashi Z, Elzi DJ, Dickey WO, Podlosky L, Clarke G, Ambruso DR: Transfusion-related acute lung injury: epidemiology and a prospective analysis of etiologic factors. Blood 2003;101:454-62.

61 Marik PE, Sibbald WJ: Effect of stored-blood transfusion on oxygen delivery in patients with sepsis. JAMA 1993;269:3024-9.

62 Walsh TS, McArdle F, McLellan SA, Maciver C, Maginnis M, Prescott RJ, McClelland DB: Does the storage time of transfused red blood cells influence regional or global indexes of tissue oxygenation in anemic critically ill patients? Crit Care Med 2004; 32:364-71.

63 Weiskopf RB, Feiner J, Hopf H, Lieberman J, Finlay HE, Quah C, Kramer JH, Bostrom A, Toy P: Fresh blood and aged stored blood are equally efficacious in immediately reversing anemia-induced brain oxygenation deficits in humans. Anesthesiology 2006;104:911-20.

64 Purdy FR, Tweeddale MG, Merrick PM: Association of mortality with age of blood transfused in septic ICU patients. Can J Anaesth 1997;44: 1256-61.
65 Edna TH, Bjerkeset T: Perioperative blood transfusions reduce long-term survival following surgery for colorectal cancer. Dis Colon Rectum 1998;41: 451-9.

66 Mynster T, Nielsen HJ: Storage time of transfused blood and disease recurrence after colorectal cancer surgery. Dis Colon Rectum 2001;44:955-64.

67 Gajic O, Rana R, Mendez JL, Rickman OB, Lymp JF, Hubmayr RD, Moore SB: Acute lung injury after blood transfusion in mechanically ventilated patients. Transfusion 2004;44:1468-74.

68 Murrell Z, Haukoos JS, Putnam B, Klein SR: The effect of older blood on mortality, need for ICU care, and the length of ICU stay after major trauma. Am Surg 2005;71:781-5.

69 Hebert PC, Chin-Yee I, Fergusson D, Blajchman M, Martineau R, Clinch J, Olberg B: A pilot trial evaluating the clinical effects of prolonged storage of red cells. Anesth Analg 2005;100:1433-8, table.

70 Basran S, Frumento RJ, Cohen A, Lee S, Du Y, Nishanian E, Kaplan HS, Stafford-Smith M, BennettGuerrero E: The association between duration of storage of transfused red blood cells and morbidity and mortality after reoperative cardiac surgery. Anesth Analg 2006;103:15-20.

71 van de Watering L., Lorinser J, Versteegh M, Westendorp R, Brand A: Effects of storage time of red blood cell transfusions on the prognosis of coronary artery bypass graft patients. Transfusion 2006; 46:1712-8.

72 Leal-Noval SR, Munoz-Gomez M, Arellano-Orden V, Marin-Caballos A, Amaya-Villar R, Marin A, Puppo-Moreno A, Ferrandiz-Millon C, FloresCordero JM, Murillo-Cabezas F: Impact of age of transfused blood on cerebral oxygenation in male patients with severe traumatic brain injury. Crit Care Med 2008;36:1290-6.

73 Koch CG, Li L, Sessler DI, Figueroa P, Hoeltge GA, Mihaljevic T, Blackstone EH: Duration of red-cell storage and complications after cardiac surgery. $\mathrm{N}$ Engl J Med 2008:358:1229-39.

74 Yap CH, Lau L, Krishnaswamy M, Gaskell M, Yii M: Age of transfused red cells and early outcomes after cardiac surgery. Ann Thorac Surg 2008;86: 554-9.

75 Weinberg JA, McGwin G Jr, Griffin RL, Huynh VQ, Cherry SA 3rd, Marques MB, Reiff DA, Kerby JD, Rue LW 3rd: Age of transfused blood: an independent predictor of mortality despite universal leukoreduction. J Trauma 2008;65:279-82.
76 Martin CM, Sibbald WJ, Lu X, Hebert P, et al.: Age of transfused red blood cells is associated with ICU length of stay. Clin Invest Med 1994;17:124.

77 Vamvakas EC, Carven JH: Length of storage of transfused red cells and postoperative morbidity in patients undergoing coronary artery bypass graft surgery. Transfusion 2000;40:101-9.

78 Keller ME, Jean R, LaMorte WW, Millham F, Hirsch E: Effects of age of transfused blood on length of stay in trauma patients: a preliminary report. J Trauma 2002;53:1023-5.

79 Leal-Noval SR, Jara-Lopez I, Garcia-Garmendia JL, Marin-Niebla A, Herruzo-Aviles A, CamachoLarana P, Loscertales J: Influence of erythrocyte concentrate storage time on postsurgical morbidity in cardiac surgery patients. Anesthesiology 2003;98: 815-22.

80 Vamvakas EC, Carven JH: Transfusion and postoperative pneumonia in coronary artery bypass graft surgery: effect of the length of storage of transfused red cells. Transfusion 1999;39:701-10.

81 Offner PJ, Moore EE, Biffl WL, Johnson JL, Silliman CC: Increased rate of infection associated with transfusion of old blood after severe injury. Arch Surg 2002;137:711-6; discussion 716-7.

82 Mynster T, Nielsen HJ: The impact of storage time of transfused blood on postoperative infectious complications in rectal cancer surgery. Danish RANX05 Colorectal Cancer Study Group. Scand J Gastroenterol 2000;35:212-7.

83 Zallen G, Offner PJ, Moore EE, Blackwell J, Ciesla DJ, Gabriel J, Denny C, Silliman CC: Age of transfused blood is an independent risk factor for postinjury multiple organ failure. Am J Surg 1999; 178:570-2.

84 Rothmann M, Braun MM, Ng TH: On the hazard ratios and corresponding confidence intervals that appear in Basran et al. (2006). Anesth Analg 2007 Jun;104:1597.

85 Benjamin RJ, Dodd RY: Red-cell storage and complications of cardiac surgery. N Engl J Med 2008; 358:2840-1.

86 Mynster T: Re: Keller ME et al. Effects of age of transfused blood on length of stay in trauma patients: a preliminary report. J Trauma 2003;55: 390-1. 